\title{
Hydrological hazard mapping in Rupandehi district, west Nepal
}

\author{
Megh Raj Dhital ${ }^{1}$, Rajendra Shrestha ${ }^{2}$, Motilal Ghimire ${ }^{3}$, \\ Ghan Bahadur Shrestha ${ }^{4}$, and Dhruba Tripathi ${ }^{4}$ \\ ${ }^{1}$ Central Department of Geology, Tribhuvan University, Kathmandu, Nepal \\ ${ }^{2}$ Butwal Power Company Pvt. Ltd, Nepal \\ ${ }^{3}$ Central Department of Geography, Tribhuvan University, Kathmandu, Nepal \\ ${ }^{4}$ Mountain Risk Engineering Unit, Tribhuvan University, Kathmandu, Nepal
}

\begin{abstract}
Large-scale (1:25,000) integrated hydrological hazard mapping was carried out in the Rupandehi district of west Nepal. The main hazard types in the study area were landslides, debris flows, floods, bank undercutting, and inundation. The maps were prepared on the basis of field observation of damages and hazards as well as using available topographic maps, digital data, satellite imageries, and aerial photographs. The information gathered was digitised and analysed using mainly ArcView and ILWIS GIS systems and HEC-RAS.
\end{abstract}

\section{INTRODUCTION}

In Nepal, hydrological disasters cause a huge loss of lives and property annually. As a first step towards mitigating or controlling such problems, it is necessary to prepare hydrological hazard maps. Consequently, the Department of Water-Induced Disaster Prevention has initiated a programme of large-scale $(1: 25,000)$ hazard mapping in some districts of Nepal. The paper summarises the outcomes of a pilot study of such efforts in the Rupandehi district of west Nepal.

The Rupandehi district (Fig. 1) lies in the Western Development Region of Nepal and its headquarters are at Bhairahawa (Siddhartha Nagar). It suffers from various types of hydrological hazards (Table 1). The study area covers about $1011.3 \mathrm{sq} \mathrm{km}$ and is accessible by roads, trails, and highways. The road network is well developed in the Terai (Table 2).

\section{PREVIOUS STUDIES}

Brunsden et al. (1975) were one of the first to develop a geomorphological map of a road corridor in Nepal. Based on their findings, the Leoti Khola-Mulghat sector of the Dharan-Dhankuta road alignment was relocated.

Kojan (1978) studied the landslide problems along the Godavari-Dandeldhura road. He identified the main hazardous areas along the road sector and recommended various methods of slope stabilisation. He also concluded that about $26 \%$ increase in landslide was due to human activities.

Wagner (1981) was probably the first to prepare a landslide and gully erosion hazard map based on field observations. For this purpose, he prepared various maps depicting rock and soil type, slope angle, aspect, and orientation of discontinuities along the Siddhartha Highway around Waling in west Nepal. Deoja et al. (1991) further developed this method and proposed various ratings for attributes such as rock type, soil type, slope angle, relative relief, groundwater, surface hydrology, folds, and faults.

Probably, the first detailed landslide hazard mapping was carried out along the Tulsipur-Sallyan, Ghorahi-Piuthan, and Piuthan-Libang roads of mid west Nepal (DoR/USAID 1986). These maps were derived from engineering geological mapping of the road alignment on a scale of 1:5000, aerial photo interpretation, and kinematic analysis of joints.

Feasibility- and detailed-stage landslide hazard mapping was carried out along the Baitadi-Darchula road alignment in far west Nepal (Dhital et al. 1991). The hazard mapping was based on the preparation of engineering geological maps, slope maps, soil type and soil depth maps, and the maps depicting the relationship between discontinuities and slope aspect. The hazard maps of feasibility stage showed overall hazard types whereas those of detailed stage depicted specific hazard types and their level.

DPTC (1996) carried out the detailed investigation, monitoring, and control of a landslide in the Ilam district of

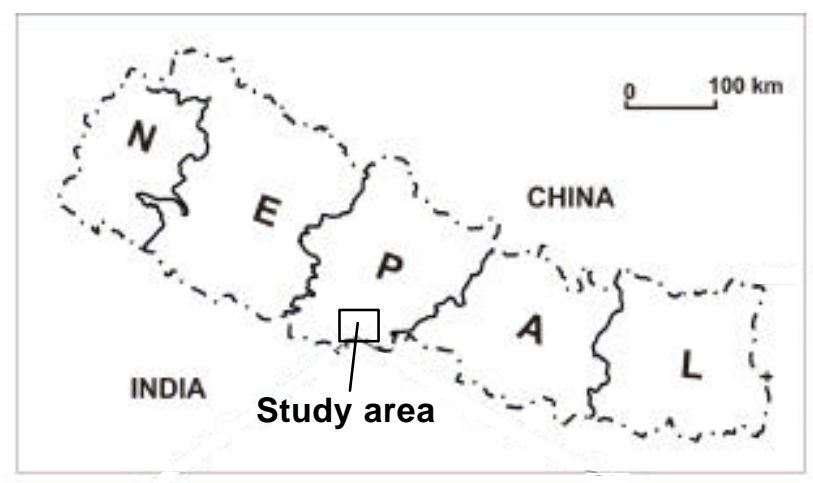

Fig. 1: Location map of the study area 
Table 1: Summary of damage by floods and landslides from 1992 to 2002 in the Rupandehi district

\begin{tabular}{|c|c|c|c|c|c|c|c|c|c|c|c|}
\hline \multirow[b]{2}{*}{ 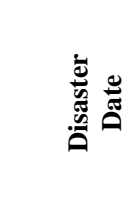 } & \multirow{2}{*}{ 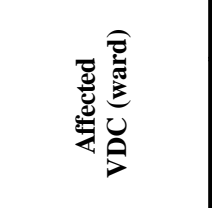 } & \multirow{2}{*}{ 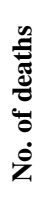 } & \multirow{2}{*}{ 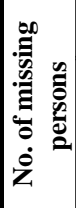 } & \multirow{2}{*}{ 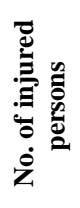 } & \multirow{2}{*}{ 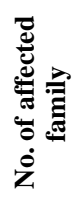 } & \multirow{2}{*}{ 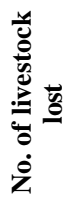 } & \multicolumn{3}{|c|}{ No. of houses damaged } & \multirow{2}{*}{ 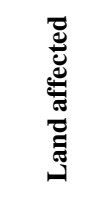 } & \multirow{2}{*}{ 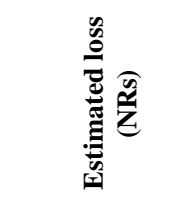 } \\
\hline & & & & & & & $\frac{\frac{2}{0}}{\frac{0}{0}}$ & 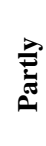 & 㞭总 & & \\
\hline 1994 & & 1 & & 0 & 1 & 0 & 0 & 0 & & & \\
\hline 1995 & & - & & - & - & - & - & - & - & - & - \\
\hline 1997 & & - & & - & - & - & - & - & - & - & - \\
\hline 1998 & & 18 & & 4 & 1448 & 1 & 128 & - & 1 & 0.14 ha & $68,190,300.00$ \\
\hline 1999 & & 4 & & 1 & 33 & 3 & 5 & 25 & 1 & & $390,500.00$ \\
\hline 2000 & & - & & - & - & - & - & - & - & - & - \\
\hline $2-8-2001$ & Kamhariya (4) & 1 & 1 & 2 & 1 & - & - & - & - & 8 Bigha & $4,500,000.00$ \\
\hline $30-7-2001$ & Majahagobha (3) & & & & 1 & & 1 & & & & 9800.00 \\
\hline
\end{tabular}

Source: Department of Narcotics Drugs Control and Natural Disaster Management, Government of Nepal. One Kattha = 1/20 of a Bigha, and one Bigha $=0.67772$ ha

Table 2: Transportation network in the Rupandehi district

\begin{tabular}{l|l}
\hline Transportation & Length, km \\
\hline Highway & 66 \\
\hline Feeder road & 33 \\
\hline District road & 250 \\
\hline Other road & 60 \\
\hline Cart tract & 204 \\
\hline Footpath & 1695 \\
\hline Runway & 4 \\
\hline Total & $\mathbf{2 3 1 2}$ \\
\hline
\end{tabular}

east Nepal. The landslide is located on the left bank of the Mai Khola, at Km 62 of the Charali-Ilam road. The landslide came into existence during the road construction in 1984, and became quite hazardous during the road maintenance of 1992 and was further aggravated in the monsoon of 1995.

DPTC (1993) prepared a flood hazard map of the Bagmati River in the Sarlahi and Rautahat districts. HMG Nepal, UNDP, and ICIMOD (2001) carried out flood hazard mapping in two VDCs of the Chitwan and two VDCs of the Bardiya districts using geographic information system and remote sensing techniques coupled with field verifications.

\section{HYDROLOGICAL ANALYSIS}

The flood data of the Tinau River atthe DHM station no. 390 (latitude: $27^{\circ} 42^{\prime} 10^{\prime \prime}$; longitude: $8^{\circ} 27^{\prime} 50^{\prime \prime}$ ) were used for estimating different return periods. The flood data of other rivers and tributaries in the study area are not available. The annual maximum instantaneous flood discharge of the Tinau River for the period from 1964 to 1969 and from 1984 to 1992 is available from DHM (Table 3). Flood estimates for different return periods were made by applying the generalised extreme value I (EVI) and log Pearson Type III methods.

Table 4 shows the flood estimates in the Tinau River at the DHM station no. 390 for various return periods. The maximum value recorded at that station was adapted for
Table 3: Maximum instantaneous annual flood discharge data of the Tinau River at DHM Station No. 390

\begin{tabular}{c|c}
\hline Year & Discharge $\left(\mathbf{m}^{3} / \mathbf{s}\right)$ \\
\hline 1964 & 417 \\
\hline 1965 & 2220 \\
\hline 1966 & 1180 \\
\hline 1967 & 1950 \\
\hline 1968 & 2000 \\
\hline 1969 & 600 \\
\hline 1984 & 390 \\
\hline 1985 & 325 \\
\hline 1986 & 644 \\
\hline 1987 & 580 \\
\hline 1988 & 565 \\
\hline 1989 & 457 \\
\hline 1990 & 260 \\
\hline 1991 & 288 \\
\hline 1992 & 134 \\
\hline
\end{tabular}

further analysis. The guideline recommended by WECS/ DHM (1990) was used as a basis for estimating the flood flows in other rivers in the study area. Table 5 shows the prorated flood flows for various return periods in different tributaries.

\section{Flood hazard mapping in the field}

For the preparation of a hazard map, traverses were made along the Tinau, Dano, Rohini, and Kanchan river, and their tributaries. During the field study, detailed information regarding old river course, flood marks, bank height, bank cutting, channel shifting, and effect of flooding on civil structures, were collected. Local people were interviewed to get information on the history of river flooding, observed flood levels, socioeconomic impact of floods, and hazard assessment perception of the community.

\section{Flood hazard mapping using numerical modelling}

Since the field investigation showed considerable variation in the flood hazard zones from the desk studystage flood hazard map, a new approach was necessary to apply. Field evidence as well as the interpretation of aerial 
Table 4: Flood estimates for the Tinau River

\begin{tabular}{l|l|l|l|l}
\hline \multicolumn{2}{c|}{} & \multicolumn{3}{|c}{ Method } \\
\cline { 3 - 5 } \multicolumn{2}{c|}{} & $\begin{array}{c}\text { Generalised } \\
\text { EVI }\end{array}$ & $\begin{array}{c}\text { Log } \\
\text { Pearson } \\
\text { Type III }\end{array}$ & Adopted \\
\hline $\begin{array}{l}\text { Flood } \\
\text { flows } \\
\left(\mathbf{m}^{3} / \mathbf{s}\right)\end{array}$ & $\mathbf{1}$ in 2-yr & 490 & 435 & 490 \\
\cline { 2 - 5 } & $\mathbf{1}$ in 5-yr & 905 & 778 & 905 \\
\cline { 2 - 5 } & $\mathbf{1}$ in 10-yr & 1180 & 1082 & 1180 \\
\cline { 2 - 5 } & $\mathbf{1}$ in 20-yr & 1440 & 1221 & 1440 \\
\cline { 2 - 5 } & $\mathbf{1}$ in 50-yr & 1786 & 2060 & 2060 \\
\hline
\end{tabular}

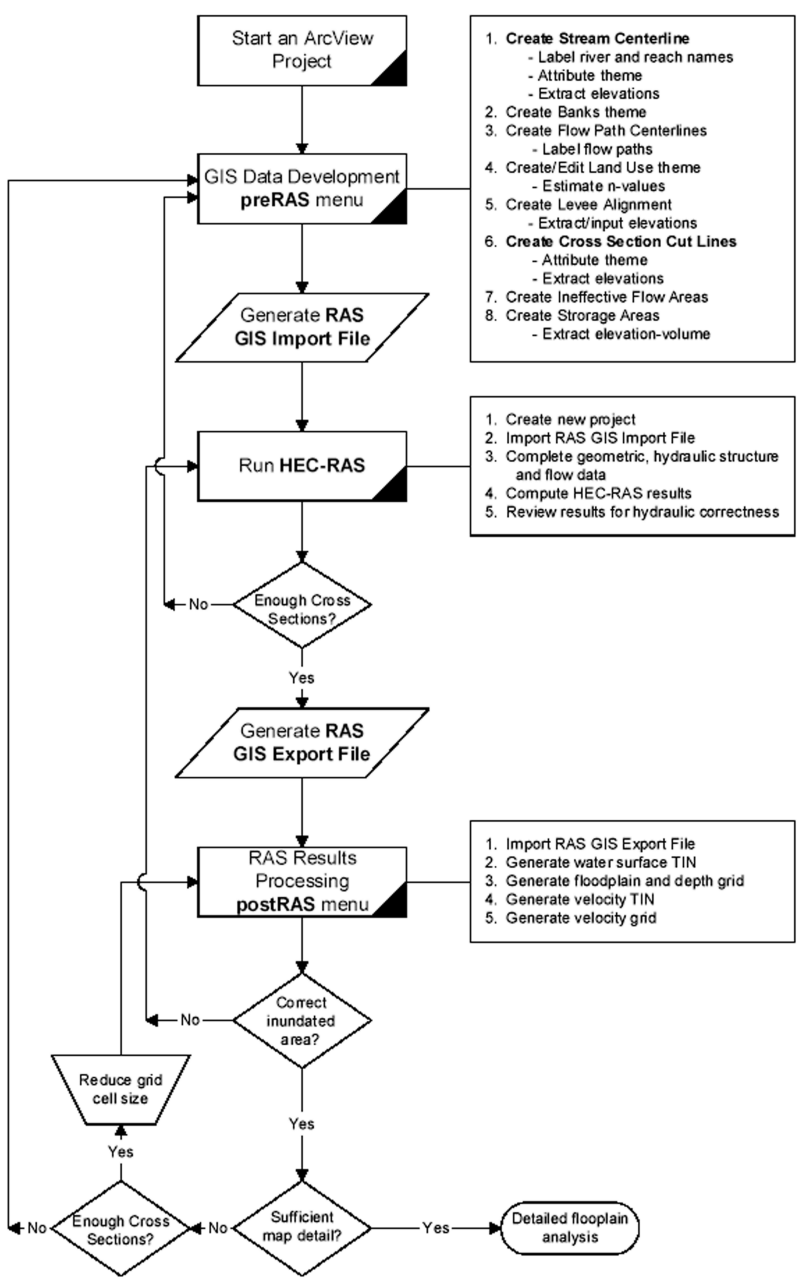

Fig. 2: Process flow diagram for using HEC-GeoRAS

photographs, topographic maps, and satellite imageries indicated that a reliable estimation of floodwater distribution in the surrounding areas is required for preparing a flood hazard map. The evaluation of hydrological, hydraulic, topographic, and social parameters were also required for this purpose. Hence, the final flood hazard map was prepared using HEC-RAS and ArcView GIS system. The floodplain analysis of the Tinau River and Dano River was carried out using one-dimensional numerical model HEC-RAS and ArcView GIS. HEC-GeoRAS extension for ArcView GIS was used as an interface between the two systems for the preprocessing and post-processing of the data in GIS.
Table 5: Flood estimates for tributaries

\begin{tabular}{l|c|c|c|c}
\hline \multirow{2}{*}{\multicolumn{1}{c|}{ Location }} & \multicolumn{4}{c}{ Flood flow, $\mathbf{~ m}^{3} / \mathbf{s}$} \\
\cline { 2 - 5 } & $\begin{array}{c}\mathbf{1} \text { in } \\
\text { 5-yr }\end{array}$ & $\begin{array}{c}\mathbf{1} \text { in } \\
\mathbf{1 0} \text {-yr }\end{array}$ & $\begin{array}{c}\mathbf{1} \text { in } \\
\mathbf{2 0 - y r}\end{array}$ & $\begin{array}{c}\mathbf{1} \text { in } \\
\mathbf{5 0 - y \mathbf { r }}\end{array}$ \\
\hline $\begin{array}{l}\text { Confluence of the Suili } \\
\text { Khola and Dano River }\end{array}$ & 42 & 56 & 72 & 118 \\
\hline $\begin{array}{l}\text { Confluence of the Baurba } \\
\text { Khola and Dano River }\end{array}$ & 64 & 85 & 109 & 173 \\
\hline Inguriya River & 202 & 266 & 334 & 503 \\
\hline $\begin{array}{l}\text { Confluence of the } \\
\text { Kanchan River and Dano } \\
\text { River }\end{array}$ & 239 & 316 & 395 & 589 \\
\hline $\begin{array}{l}\text { Tributary from the village } \\
\text { Dhamasar }\end{array}$ & 58 & 78 & 99 & 159 \\
\hline
\end{tabular}

During the pre-processing of the GIS data, a triangulated irregular network (TIN) was prepared from available contours and spot elevations. A series of line themes pertinent to developing geometrical data for HEC-RAS were created. The themes created are stream centre line, flow path centre line, main channel banks, and cross-sectional cut lines. An overview of the HEC-GeoRAS process is shown Fig. 2. After creating each RAS theme, GIS data (geometric data) were exported to run in HEC-RAS. The plan of the Tinau and Dano Rivers generated by ArcView GIS is shown in Fig. 3.

In the HEC-RAS, after importing the geometric data extracted from GIS, hydraulic data were entered. Flow data and associated boundary condition were also supplied. In the next step, water surface profile calculation for the flood of 5, 10, 20 and 50 year return periods were performed with a subcritical flow regime. Once the water surface profiles were calculated, the results were exported to GIS format.

At the last step, HEC-RAS results were imported into the GIS system and a floodplain map for each profile was developed. The longitudinal profiles of the two rivers are presented in Fig. 4 whereas a few typical cross-sections of the Tinau River are shown in Fig. 5 and 6, and a crosssection of the Dano River is given in Fig. 7. The plots of discharge versus water surface elevation at their respective locations are indicated in Fig. 8, 9, and 10. A flood hazard classification scheme based on this analysis is shown in Table 6, and flood hazard in the district is depicted in the integrated hydrological hazard map (Fig. 11).

\section{HAZARD MAPPING}

A landslide hazard map was prepared using the GIS based bivariate statistical technique developed by the International Institute of Aerospace Survey and Earth Sciences (ITC), the Netherlands. It is based on the quantitatively defined weight values. A weight value for a parameter class is defined as the natural logarithm of the landslide density in the class divided by the landslide density in the entire map. It is expressed as:

$$
W i=\ln (\text { DenseClass } / \text { DenseMap })=\ln \frac{N P I X(S i) / N P I X(N i)}{\sum N P I X(S i) / \sum N P I X(N i)}
$$




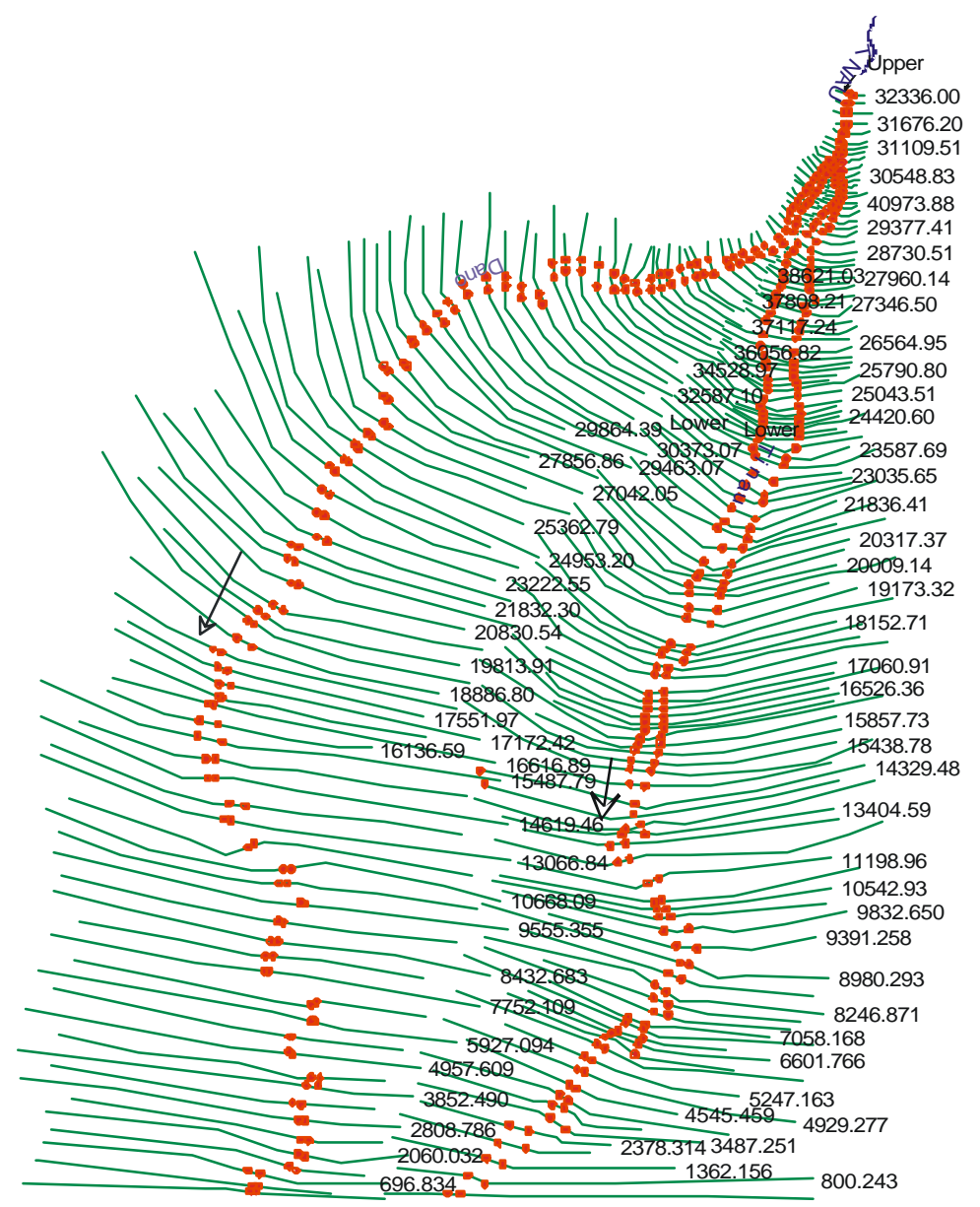

Fig. 3: Plan depicting river centre line, cross-section lines, and river stations of the Tinau and Dano Rivers

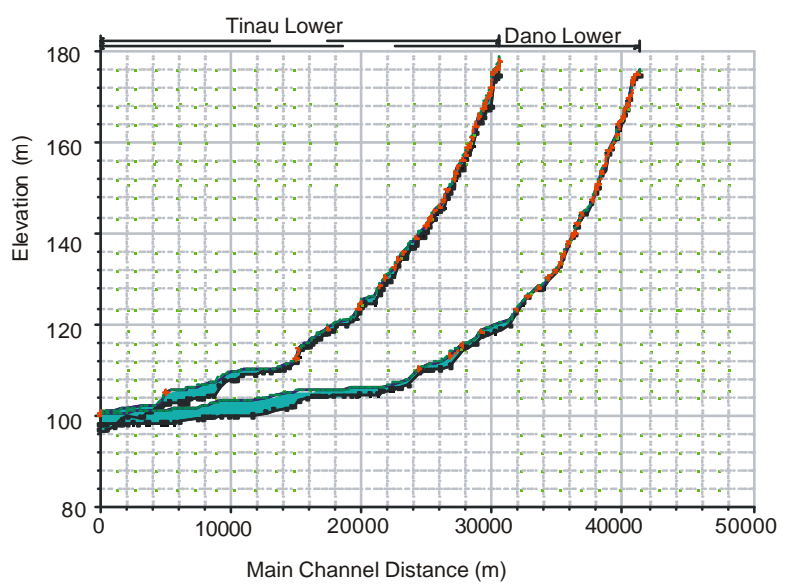

Fig. 4: Longitudinal profiles of the Tinau and Dano Rivers

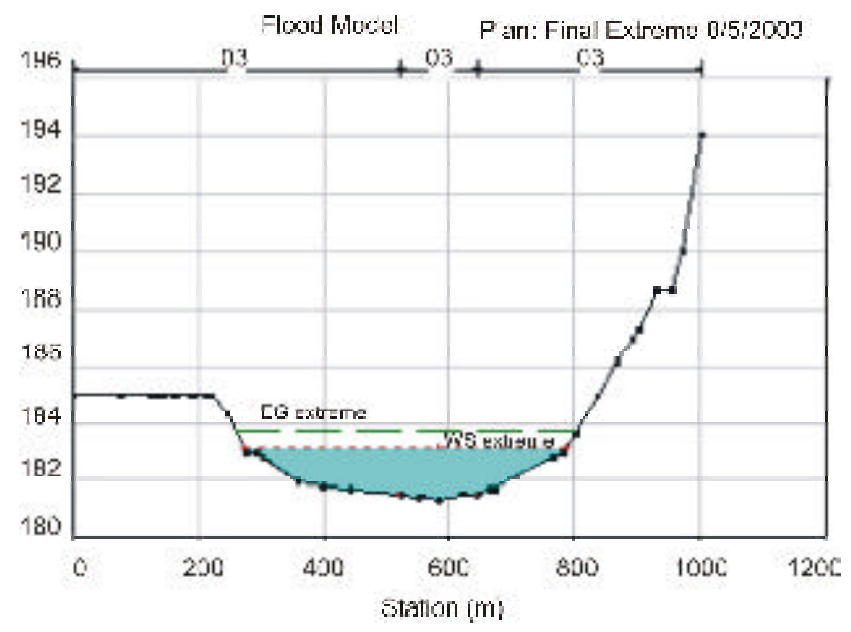

Fig. 5: Cross-section of the Tinau River (upper reach) at RS 31109.51 


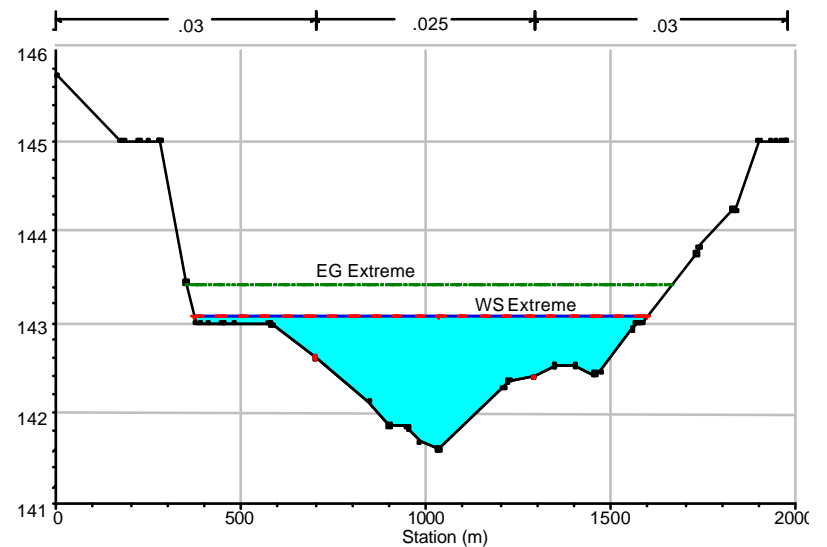

Fig. 6: Cross-section of the Tinau River (lower reach) at RS 25432.96

Flood Model Plan: Final Extreme 8/5/2003

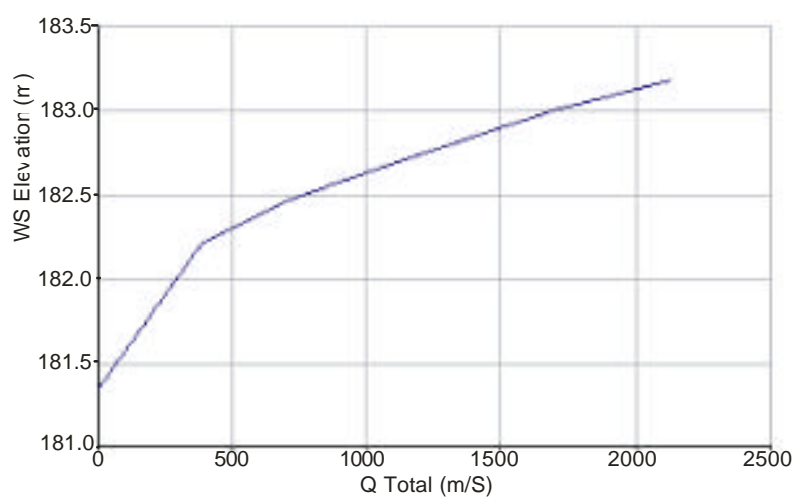

Fig. 8: Plot of discharge versus water surface elevation for the Tinau River (upper reach) at RS 31109.51

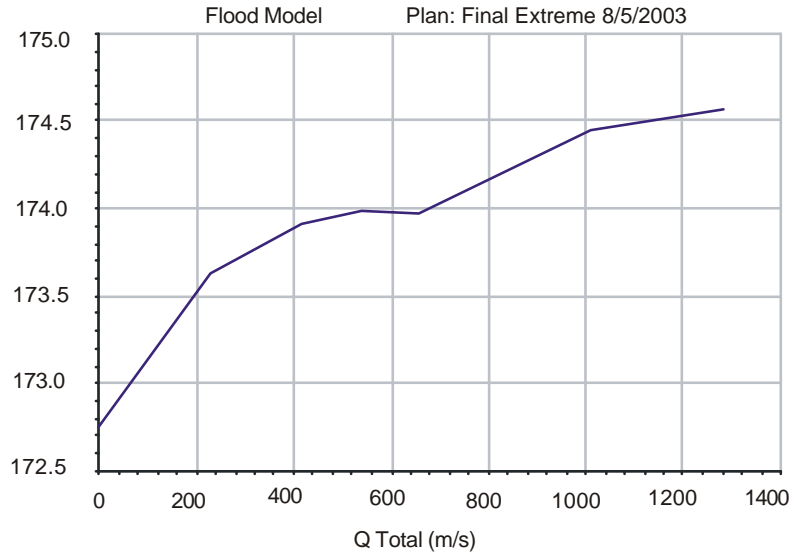

Fig. 10: Plot of discharge versus water surface elevation for the Dano River at RS 40973

where $W i=$ the weight given to a certain parameter class, Dense Class = the landslide density within the parameter class, Dense Map = the landslide density within the entire map, $N P I X(S i)=$ number of pixels containing landslide in a

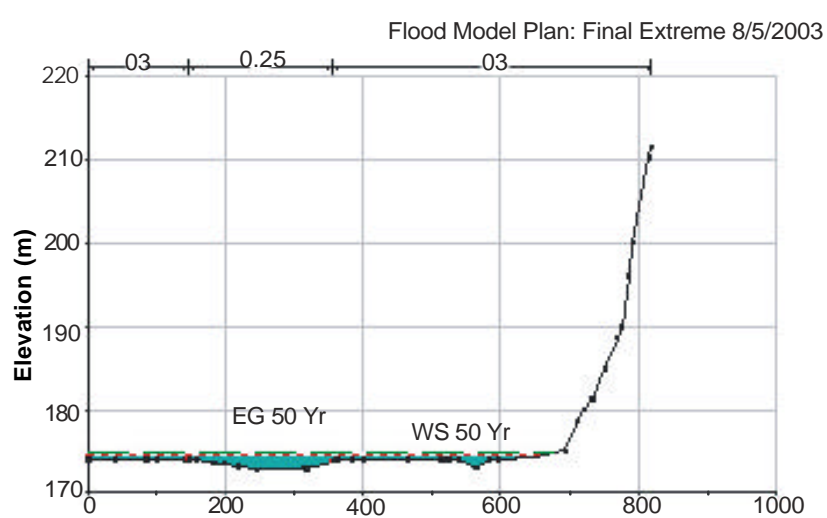

Fig. 7: Cross-section of the Dano River at RS 40973.88

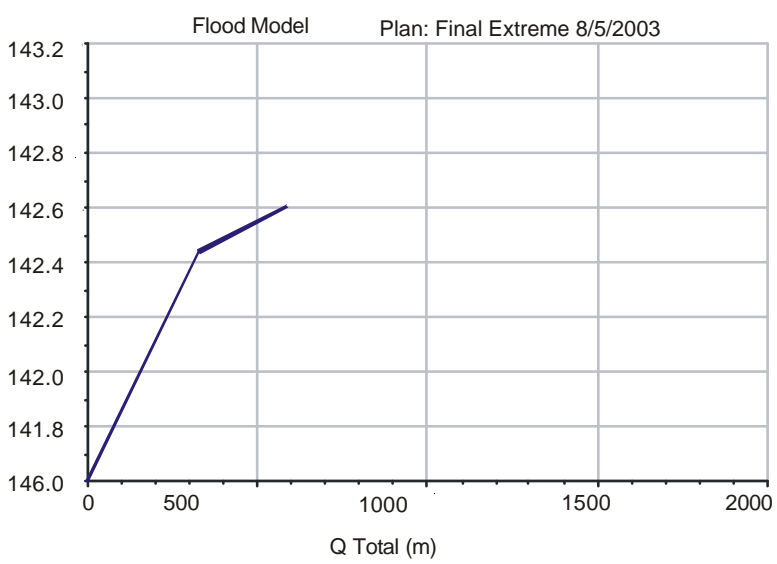

Fig. 9: Plot of discharge versus water surface elevation for the Tinau River (lower reach) at RS 25432.96

certain parameter class, and NPIX $(\mathrm{Ni})=$ total number of pixels in a certain parameter class.

To calculate the weights, a cross table (Table 7) was obtained by map crossing on ILWIS 2.1 GIS and Image Processing System developed by ITC. All input values for the formula were obtained from the cross table. The natural logarithm was used to give a negative weight when the landslide density was lower than the normal and a positive weight when it was higher than the normal.

The following maps were used to obtain the landslide and gully erosion hazard map:

-Weight map of slope gradient,

-Weight map of slope aspect,

-Weight map of land use and land cover,

-Weight map of fault distance,

-Weight map of relative relief,

-Weight map of geology,

-Weight map of slope shape, and

-Weight map of vegetation density. 
Table 6: Flood hazard classification

\begin{tabular}{c|c}
\hline Hazard type & Depth of water $(\mathbf{m})$ \\
\hline Very High & $>1.6$ \\
\hline High & $0.8-1.6$ \\
\hline Moderate & $0-0.8$ \\
\hline Low & \\
\hline
\end{tabular}

Table 7: Cross table of landslide hazard mapping attributes used in the bivariate analysis

\begin{tabular}{|c|c|c|c|c|c|}
\hline \multicolumn{6}{|c|}{ 1. Slope gradient } \\
\hline Slope (degrees) & Count & Landslide count & Landslide density & Coefficient & Weight \\
\hline$<15$ & 1573694 & 4093 & 0.0026 & 0.0065 & -0.92 \\
\hline $15-25$ & 589365 & 4264 & 0.0072 & 0.0065 & 0.10 \\
\hline $25-35$ & 412262 & 5355 & 0.0130 & 0.0065 & 0.69 \\
\hline $35-45$ & 46619 & 862 & 0.0185 & 0.0065 & 1.05 \\
\hline$>45$ & 41897 & 2456 & 0.0586 & 0.0065 & 2.20 \\
\hline \multicolumn{6}{|c|}{ 2. Slope aspect } \\
\hline Aspect & Count & Landslide count & Landslide density & Coefficient & Weight \\
\hline Flat & 247285 & 239 & 0.0010 & 0.0065 & -1.87210 \\
\hline North & 91240 & 89 & 0.0010 & 0.0065 & -1.87210 \\
\hline Northeast & 44798 & 128 & 0.0029 & 0.0065 & -0.80699 \\
\hline East & 962753 & 8034 & 0.0083 & 0.0065 & 0.24444 \\
\hline Southeast & 130394 & 786 & 0.0060 & 0.0065 & -0.08002 \\
\hline South & 154690 & 612 & 0.0040 & 0.0065 & -0.48548 \\
\hline Southwest & 118231 & 768 & 0.0065 & 0.0065 & 0.00000 \\
\hline West & 952062 & 6583 & 0.0069 & 0.0065 & 0.05968 \\
\hline Northwest & 98 & 0 & 0.0001 & 0.0065 & -4.17339 \\
\hline \multicolumn{6}{|c|}{ 3. Land use pattern } \\
\hline Land use type & Count & Landslide count & Landslide density & Coefficient & Weight \\
\hline Built-up area & 27785 & 0 & 0.0001 & 0.0065 & -4.17339 \\
\hline Buildings & 8 & 0 & 0.0001 & 0.0065 & -4.17339 \\
\hline Cutting & 6929 & 1248 & 0.1801 & 0.0065 & 3.32171 \\
\hline Cultivation & 342846 & 135 & 0.0004 & 0.0065 & -2.78872 \\
\hline Forest & 2162130 & 15239 & 0.0070 & 0.0065 & 0.07409 \\
\hline Bush & 112524 & 564 & 0.0050 & 0.0065 & -0.26240 \\
\hline Sand & 37323 & 50 & 0.0013 & 0.0065 & -1.60944 \\
\hline Barren land & 5511 & 0 & 0.0001 & 0.0065 & -4.17339 \\
\hline Riverbed & 5097 & 0 & 0.0001 & 0.0065 & -4.17339 \\
\hline Pond or lake & 905 & 0 & 0.0001 & 0.0065 & -4.17339 \\
\hline \multicolumn{6}{|c|}{ 4. Fault zone } \\
\hline Distance above fault & Count & Landslide count & Landslide density & Coefficient & Weight \\
\hline Within $200 \mathrm{~m}$ & 89872 & 100 & 0.0011 & 0.0065 & -1.77667 \\
\hline Others & 2617396 & 17143 & 0.0065 & 0.0065 & 0.00000 \\
\hline \multicolumn{6}{|c|}{ 5. Relative relief } \\
\hline Relief class & Count & Landslide count & Landslide density & Coefficient & Weight \\
\hline Flat $(<1)$ & 448394 & 31 & 0.0001 & 0.0065 & -4.17339 \\
\hline Low $(1-20)$ & 1139348 & 2836 & 0.0025 & 0.0065 & -0.95555 \\
\hline Medium $(20-40)$ & 956107 & 8331 & 0.0087 & 0.0065 & 0.29155 \\
\hline High $(>40)$ & 121387 & 5855 & 0.0482 & 0.0065 & 2.00356 \\
\hline \multicolumn{6}{|c|}{ 6. Geology } \\
\hline Category & Count & Landslide count & Landslide density & Coefficient & Weight \\
\hline Alluvial deposits & 598359 & 15 & 0.0001 & 0.0065 & -4.17339 \\
\hline Middle Siwaliks & 829234 & 9009 & 0.0109 & 0.0065 & 0.51695 \\
\hline Lower Siwaliks & 1274898 & 8219 & 0.0064 & 0.0065 & -0.01552 \\
\hline \multicolumn{6}{|c|}{ 7. Slope shape } \\
\hline Slope shape type & Count & Landslide count & Landslide density & Coefficient & Weight \\
\hline Concave & 1048350 & 9989 & 0.0095 & 0.0065 & 0.37946 \\
\hline Straight & 636877 & 324 & 0.0005 & 0.0065 & -2.56525 \\
\hline Convex & 1016324 & 6926 & 0.0068 & 0.0065 & 0.04516 \\
\hline \multicolumn{6}{|c|}{ 8. Vegetation } \\
\hline Vegetation density & Count & Landslide count & Landslide density & Coefficient & Weight \\
\hline Sparse & 421859 & 3041 & 0.0072 & 0.0065 & 0.10229 \\
\hline Moderate & 640159 & 3679 & 0.0057 & 0.0065 & -0.13136 \\
\hline Moderately dense & 230165 & 880 & 0.0038 & 0.0065 & -0.53683 \\
\hline Dense & 1395684 & 8160 & 0.0058 & 0.0065 & -0.11395 \\
\hline
\end{tabular}

Note: Coefficient $=$ total landslide count/total count $($ which is about 0.0065$)$ 


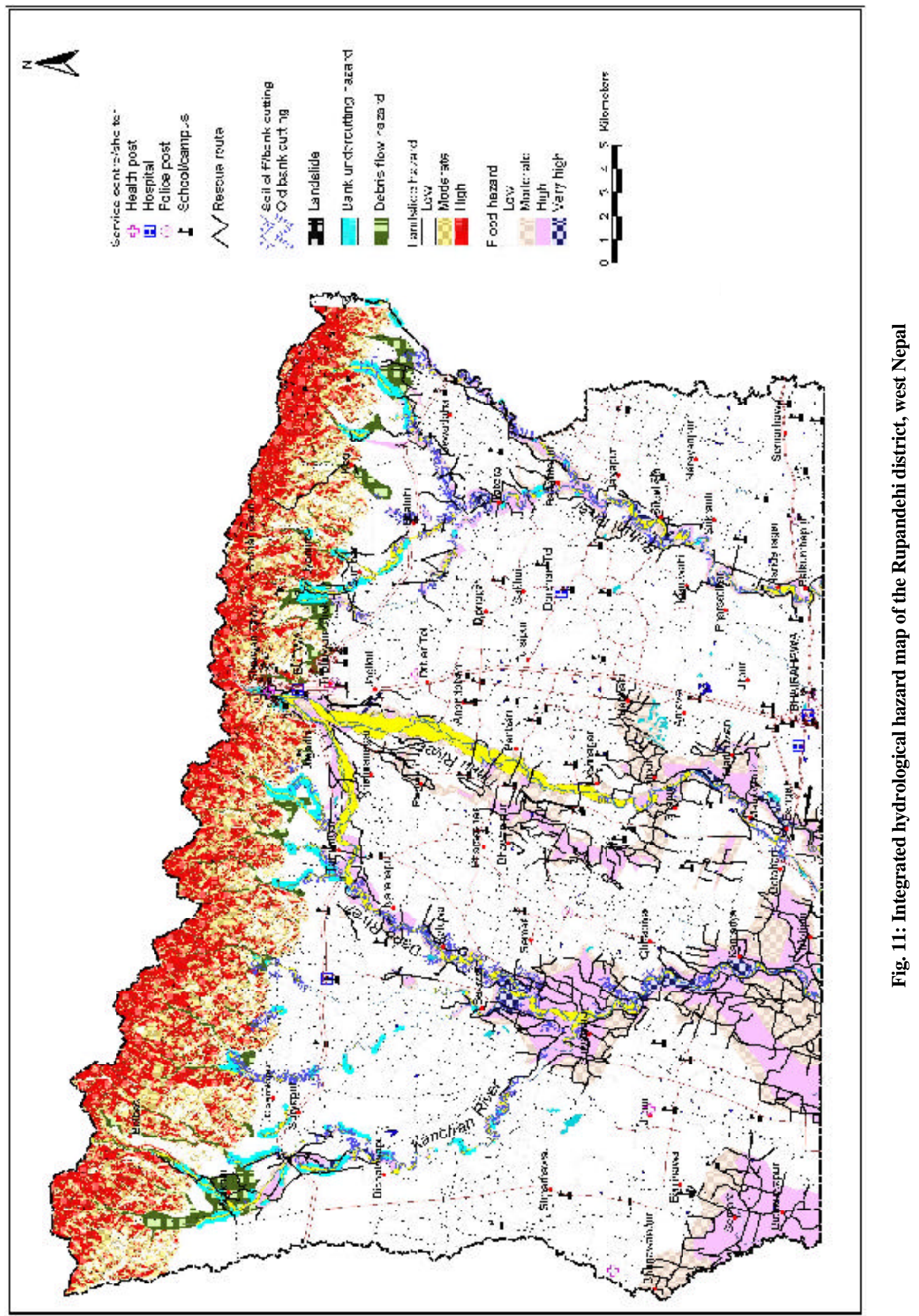


Table 8: Distribution of areas under various landslide hazard categories

\begin{tabular}{l|r|r|r|r}
\hline \multirow{2}{*}{ Category } & \multicolumn{2}{|c|}{ Landslide hazard } & \multicolumn{2}{c}{ Landslide area } \\
\cline { 2 - 5 } & $\mathbf{k m}^{2}$ & Per cent & $\mathbf{k m}^{2}$ & Per cent \\
\hline Low & 117.42 & 44.28 & 0.15 & 9.83 \\
\hline Moderate & 68.88 & 25.97 & 0.33 & 21.23 \\
\hline High & 78.9 & 29.75 & 1.08 & 68.94 \\
\hline Total & $\mathbf{2 6 5 . 2}$ & $\mathbf{1 0 0}$ & $\mathbf{1 . 5 6}$ & $\mathbf{1 0 0}$ \\
\hline
\end{tabular}

Source: Landslide hazard map

The landslide hazard map was obtained by adding all the above weights (Table 7) and classifying into the following three hazard categories :

- $\quad$ Low (weight less than -1),

- Moderate (between -1 and 0.4), and

- $\quad$ High (more than 0.4).

The distribution of the study area in various hazard categories is shown in Table 8.

\section{Debris flow hazard map}

The debris flow hazard map was prepared on the basis of aerial photo and satellite imagery interpretation, field observation, GIS analysis of digital data. For this purpose, the slope gradient ranging between 2 and 20 degrees in the vicinity of gullies and streams was considered. The hazard map was further enhanced applying vertical buffering of bank height measured in the field.

\section{Hydrological hazard map}

A unified hydrological hazard map (Fig. 11) of the Rupandehi district was generated by combining all the hazard maps. This map shows landslide, debris flow, and gully erosion hazard in the upper reaches of the Rohini, Tinau, Dano, and Kanchan Rivers as well as flood and bank undercutting hazard in their lower reaches.

\section{RESCUE ROUTES, SERVICE CENTRES, AND SHELTERS}

The main rescue routes to nearby service centres and shelters were identified during the field study as well as from the available topographic maps. Nearby schools and university campuses are considered to be the places of shelter whereas hospitals, health posts, and police post are categorised under the service centre.

\section{CONCLUSIONS}

The study area has suffered from various types of hydrological disasters, and the prominent ones were landslides, debris flows, floods, bank undercutting, and inundation. Adverse geological conditions, prolonged and high-intensity rainfall, and anthropogenic factors played a major role in triggering a variety of mass movements in this area. The integrated hydrological hazard mapping methodology was based on a comparison of field data with the computer-generated models. This work showed that it is possible in Nepal to develop a fairly reliable hydrological hazard map based on the available digital data, aerial photographs, and satellite imageries together with a good deal of field observation.

\section{ACKNOWLEDGEMENTS}

We acknowledge the Mountain Risk Engineering Unit of Tribhuvan University and the Department of Water-Induced Disaster Prevention, Government of Nepal, for granting permission to publish this paper.

\section{REFERENCES}

Brunsden, D., Doornkamp, J. C., Fookes, P. G., Jones, D. K. C., and Kelly, J. M. H., 1975, Large-scale geotechnical mapping and highway engineering design. Quarterly Jour. Engg. Geol., v. 8, pp. 227-253.

Deoja, B, Dhital, M., Thapa, B., and Wagner, A., 1991, Mountain Risk Engineering Handbook. ICIMOD, Kathmandu, Nepal, v. 1 and 2, 875 p.

Dhital, M. R., Upreti, B. N., Dangol, V., Bhandari, A. N., and Bhattarai, T. N., 1991, Engineering geological methods applied in mountain road survey - an example from Baitadi-Darchula Road Study. Jour Nepal Geol. Soc., v. 7, pp. 49-67.

DoR/USAID, 1986, Rapti Road Assessment Study, Engineering Studies, Final Technical Report (Vol. II). Unpublished report submitted to the Department of Roads (DoR) and the USAID by Luis Berger International Inc. and East Consult (P) Ltd. (unpubl.)

DPTC (Water Induced Disaster Prevention Technical Centre), 1996, A Technical Guideline on Landslide Prevention Works. Government of Nepal, Ministry of Water Resources, Water Induced Disaster Prevention Technical Centre, Pulchowk, Lalitpur, $50 \mathrm{p}$.

DPTC, 1993, Flood hazard map of Bagmati River in Tarai. Onepage leaflet published by DPTC, Ministry of Water Resources, Pulchowk, Lalitpur.

HMG Nepal, UNDP, and ICIMOD, 2001, Hazard and Risk Mapping (Electronic copy).

ILWIS, 1997, ILWIS 2.1 for Windows, Applications Guide. Published by ILWIS Department, International Institute for Aerospace Survey and Earth Sciences, Enschede, the Netherlands, 352 p.

Kojan, E., 1978, Report on landslide problems, Western Hill Road Study, Godavari to Dandeldhura, Nepal. report submitted to USAID (unpubl.).

Wagner, A., 1981, Rock structure and slope stability study of Waling area, central west Nepal. Jour. Nepal Geol. Soc. v. 1(2), pp. 37-43.

WECS/DHM., 1990, Methodologies for Estimating Hydrological Characteristics of Ungauged Locations in Nepal (2 volumes). HMGN Ministry of Water Resources, Water and Energy Commission Secretariat and Department of Hydrology and Meteorology. July 1990. 